\title{
Purification and antibacterial activities of an L-amino acid oxidase from king cobra (Ophiophagus hannah) venom
}

Phua CS (1), Vejayan J (2), Ambu S (1), Ponnudurai G (1), Gorajana A (1)

(1) Faculty of Medicine and Health, International Medical University, Kuala Lumpur, Malaysia; (2) School of Medicine and Health Sciences, Monash University, Sunway Campus, Selangor Darul Ehsan, Malaysia.

\begin{abstract}
Some constituents of snake venom have been found to display a variety of biological activities. The antibacterial property of snake venom, in particular, has gathered increasing scientific interest due to antibiotic resistance. In the present study, king cobra venom was screened against three strains of Staphylococcus aureus [including methicillin-resistant Staphylococcus aureus (MRSA)], three other species of gram-positive bacteria and six gram-negative bacteria. King cobra venom was active against all the 12 bacteria tested, and was most effective against Staphylococcus spp. (S. aureus and S. epidermidis). Subsequently, an antibacterial protein from king cobra venom was purified by gel filtration, anion exchange and heparin chromatography. Mass spectrometry analysis confirmed that the protein was king cobra L-amino acid oxidase (Oh-LAAO). SDS-PAGE showed that the protein has an estimated molecular weight of $68 \mathrm{kDa}$ and $70 \mathrm{kDa}$ under reducing and non-reducing conditions, respectively. The minimum inhibitory concentrations (MIC) of Oh-LAAO for all the 12 bacteria were obtained using radial diffusion assay method. Oh-LAAO had the lowest MIC value of $7.5 \mu \mathrm{g} / \mathrm{mL}$ against S. aureus ATCC 25923 and ATCC 29213, MRSA ATCC 43300, and S. epidermidis ATCC 12228. Therefore, the LAAO enzyme from king cobra venom may be useful as an antimicrobial agent.
\end{abstract}

Key words: L-amino acid oxidase, king cobra, antibacterial activity, Ophiophagus hannah.

\section{INTRODUCTION}

Snake venoms produce numerous biological effects and have therefore proven to be very useful to mankind. Amongst all the different biological properties that snake venoms have, one in particular has become more significant lately, and probably will become increasingly important over next years -its antimicrobial action. Infections have become increasingly difficult to treat as microorganisms have been developing resistance to the current available antimicrobial agents. Examples of bacterial species that have developed resistance to conventional antibiotics are Pseudomonas, Klebsiella, Enterobacter, Acinetobacter, Mycobacterium, Salmonella,
Staphylococcus, Enterococcus and Streptococcus (1, 2). Therefore, we are looking for new sources for the development of novel antimicrobial agents.

Despite heavy oral and fang contamination of snakes with a broad variety of potentially pathogenic bacteria, it could be observed that snake envenomations are rarely associated with bacterial infections (3). This observation led to the hypothesis that antibacterial components present in venoms may protect snakes after consuming contaminated prey (4).

One of the first studies on antibacterial activity of snake venom was carried out in 1948. It raised the hypothesis that bactericidal effects would probably be present in snake venom since it is predominantly a mixture of lysins (5). Currently, 
it is known that snake venoms contain some antibacterial constituents, such as L-amino acid oxidases, phospholipases $\mathrm{A}_{2}$, and peptides. However, the antibacterial efficacy of these proteins differs among snake species.

Previous studies reported that venom from different species of snakes has shown promising results against common infectious bacteria, such as Staphylococcus aureus, Escherichia coli, Pseudomonas aeruginosa, Bacillus subtilis, Proteus vulgaris, Proteus mirabilis and Enterobacter aerogenes (6-10). A study reported that phospholipase $\mathrm{A}_{2}\left(\mathrm{PLA}_{2}\right)$ enzymes from eastern diamondback rattlesnake (Crotalus adamanteus) and Russell's viper (Vipera russellii) exhibit comparable efficacy to chloramphenicol and ceftazidime against Burkholderia pseudomallei (11).

Multiple effects of the LAAO enzymes are reported in the literature. For instance, a report showed leishmanicidal, antitumoral and bactericidal activities of LAAO from Neuwied's lancehead (Bothrops pauloensis), while another study showed antigenic, microbicidal, and antiparasitic activities of LAAO from jararaca (Bothrops jararaca) $(6,12)$. A recent investigation on the antibacterial activity of PLA 2 isolated from Chinese pallas (Agkistrodon halys) has led to the belief that PLA 2 acts by permeabilizing the bacterial membrane by forming pores (13).

King cobra has a high venom yield, with an average of about $420 \mathrm{mg}$ of dry weight per snake (14). Recently, cathelicidin isolated from king cobra venom has been reported to have potent antibacterial activity against gram-negative bacteria (15). In addition, the L-amino acid oxidase enzyme of the king cobra was tested for its antibacterial action against Staphylococcus aureus, Staphylococcus epidermidis, Pseudomonas aeruginosa, Klebsiella pneumoniae, and Escherichia coli (16). In a preliminary screening of 11 different snake venoms, although none of the venom showed antibacterial activity against gram-negative Pseudomonas aeruginosa and Escherichia coli, king cobra venom showed one of the best antibacterial efficacy against Staphylococcus aureus (17). Therefore, in this study, we continued to investigate the king cobra venom action against various bacteria and to isolate the active antibacterial components from this venom.

\section{MATERIALS AND METHODS}

\section{Materials}

A pool of king cobra venom was obtained from a snake and reptile farm in Malaysia. The venom was lyophilized and stored at $-20^{\circ} \mathrm{C}$ until use. The bacteria used were: Staphylococcus aureus ATCC 25923, S. aureus ATCC 29213, MRSA ATCC 43300, S. epidermidis ATCC 12228, Bacillus subtilis ATCC 6633, B. cereus ATCC 10987, Salmonella enteritidis ATCC 13076, Pseudomonas aeruginosa ATCC 27853, Serratia marcescens ATCC 21074, Klebsiella pneumoniae ATCC 13883, Escherichia coli ATCC 25922 and Enterobacter cloacae ATCC 13047, courtesy of International Medical University, Malaysia, and Monash University Sunway Campus, Malaysia. All bacteria were grown on nutrient agars at $37^{\circ} \mathrm{C}$ for 24 hours. Additional work was done on three fungi: Cryptococcus neoformans ATCC 14116, Candida albicans ATCC 14028 and Candida tropicalis ATCC 1369. The fungi were streaked onto Sabouraud-dextrose agar plates and left in the incubator at $37^{\circ} \mathrm{C}$ till adequate growth was seen. Sephadex ${ }^{\mathrm{Tx}}$ G-75, Q-Sepharose ${ }^{\mathrm{Tx}} \mathrm{HP}$, HiTrap $^{\text {rm }}$ Desalting columns $(5 \mathrm{~mL})$ and HiTrap ${ }^{\text {ru }}$ Heparin HP column (5 mL) were purchased from GE-Healthcare (Sweden). Antibiotics were purchased from EMD Biosciences (USA).

\section{Antibacterial Screening of Crude Venom}

Individual colonies of bacteria were added into $5 \mathrm{~mL}$ of Mueller-Hinton broth to attain approximately $1 \times 10^{8}$ colony forming units, which corresponded to $A_{600}=0.1$ on the spectrophotometer. A total of $3 \mathrm{~mL}$ of each bacterial suspension was pipetted onto MuellerHinton agar plates. After five minutes, excess inoculum was poured away. Using a modified hole-plate method, evenly spaced holes of $4 \mathrm{~mm}$ diameter were made onto the Mueller-Hinton agar surfaces (18). Subsequently, king cobra venom was reconstituted in PBS at concentrations of 1.0 $\mathrm{mg} / \mathrm{mL}, 1.5 \mathrm{mg} / \mathrm{mL}$ and $2.0 \mathrm{mg} / \mathrm{mL}$, similar to the concentrations used in the preliminary study (17). The holes made on the Mueller-Hinton agar were then filled with $30 \mu \mathrm{L}$ of the different venom concentrations. For the positive control, $0.03 \mathrm{mg} / \mathrm{mL}$ of vancomycin and $0.03 \mathrm{mg} / \mathrm{mL}$ of doxycycline were used during screening of grampositive and gram-negative bacteria respectively. PBS was used as negative control. Plates were 
incubated at $37^{\circ} \mathrm{C}$ for 24 hours and inhibition zones were measured in triplicates, if any.

\section{Bioassay Guided Purification of Antibacterial constituent}

Antibacterial assays with $S$. aureus ATCC 25923 and ATCC 29213, and MRSA ATCC 43300 were used to guide the purification procedure. All chromatography fractions were tested for antibacterial activity using the similar modified hole-plate method that was used for antibacterial screening of crude venom. Only the fractions showing the highest antibacterial activity were further processed in the next chromatography step.

The first purification step was done by gel filtration chromatography. A total of $100 \mathrm{mg}$ of lyophilised king cobra venom was reconstituted in $1 \mathrm{~mL}$ of running buffer $(50 \mathrm{mM}$ ammonium acetate, $\mathrm{pH}$ 7.0). The venom was loaded onto a G-75 column pre-equilibrated with running buffer, collecting fractions at a twominute interval. Each fraction was measured spectrophotometrically at $280 \mathrm{~nm}$. Fractions were pooled according to the chromatographic profile. The pooled fractions were lyophilized and tested for antibacterial activity.

The gel filtration fraction exhibiting antibacterial activity was reconstituted in a starting buffer $(20 \mathrm{mM}$ tris- $\mathrm{HCl}, \mathrm{pH}$ 7.6) and loaded onto a Q Sepharose HP anion exchange column pre-equilibrated with the starting buffer. Fractions were eluted using a linear 0-0.5 M $\mathrm{NaCl}$ gradient at $1.5 \mathrm{~mL} /$ tube. To remove tris, sodium chloride and low-molecular weight contaminants, the fractions from anion exchange chromatography were desalted using prepacked HiTrap ${ }^{\mathrm{TM}}$ Desalting columns containing Sephadex ${ }^{\text {TM }}$ G-25 superfine columns. The buffer used was Milli-Q ${ }^{\circledR}$ Ultrapure Water (Merck Millipore, USA). The fractions were subsequently lyophilized and tested for antibacterial activity.

The anion exchange fraction exhibiting the highest antibacterial activity was reconstituted in a starting buffer $(20 \mathrm{mM}$ tris- $\mathrm{HCl}, \mathrm{pH} 7.6)$ and loaded onto HiTrap ${ }^{\mathrm{TM}}$ Heparin affinity chromatography previously equilibrated with the starting buffer. Fractions were eluted using a linear $0-0.5 \mathrm{M} \mathrm{NaCl}$ gradient at $1.5 \mathrm{~mL} /$ tube. Similar to anion exchange chromatography, pooled fractions were desalted using HiTrap ${ }^{\mathrm{TM}}$ Desalting columns, lyophilized and tested for antibacterial activity.

\section{Sodium Dodecyl Sulfate Polyacrylamide Gel Electrophoresis (SDS-PAGE)}

SDS-PAGE was performed on the active chromatographic fractions according to the method of Laemmli (19). The gel was stained with Coomassie brilliant blue R-250. Precision PlusProtein ${ }^{\mathrm{TM}}$ Kaleidoscope ${ }^{\mathrm{TM}}$ standards (BioRad, USA) molecular weight marker and Amersham ${ }^{\mathrm{TM}}$ Low Molecular Weight SDS electrophoresis (GE Healthcare, UK) marker were used. Subsequently, silver staining was performed under nonreducing and reducing conditions (protein was heated at $95^{\circ} \mathrm{C}$ for five minutes).

\section{Protein Quantification}

Protein concentration was determined by the Bradford method (20).

\section{Identification of Antibacterial Protein Using Mass Spectrometry}

Purified protein was analyzed with matrixassisted laser desorption ionization-time of flight (MALDI-TOF) by Proteomics International (Australia). From the Mascot database search, peptide mass fingerprinting was used to identify the antibacterial protein of interest.

\section{Minimum Inhibitory Concentrations (MICs)}

The MIC values were determined using concentrations derived from serial twofold dilutions as recommended by CLSI, starting with $220 \mu \mathrm{g} / \mathrm{mL}$ of the purified antibacterial constituent from king cobra venom (21). Using the radial diffusion assay method, antibacterial constituent isolated from king cobra venom was screened for antibacterial activity against all 12 bacteria using the similar screening method for crude king cobra venom previously performed (22). The MIC was determined as the minimum concentration of the antibacterial constituent forming a visually detectable clear zone larger than the size of the well ( $4 \mathrm{~mm}$ ) under the current experimental conditions(22).

\section{Antifungal Screening of King Cobra Venom}

Some additional work was done to test king cobra venom for antifungal activity. The antifungal screening was done on three different fungal species using $1.0 \mathrm{mg} / \mathrm{mL}, 1.5 \mathrm{mg} / \mathrm{mL}$ and 2.0 $\mathrm{mg} / \mathrm{mL}$ of crude the venom. The modified holeplate method used for antibacterial screening was used for antifungal testing in a similar way. For 
positive control during the screening, $0.03 \mathrm{mg} /$ $\mathrm{mL}$ of amphotericin $\mathrm{B}$ was prepared by diluting $0.03 \mathrm{mg}$ of amphotericin B in $1 \mathrm{~mL}$ of PBS. PBS was used as negative control.

\section{RESULTS}

\section{Antibacterial Screening of Crude Venom}

The antibacterial activity of king cobra venom against six gram-positive bacteria was tested using three different concentrations of the venom (Table 1). The inhibition zones increased with increasing venom concentration. Staphylococcus aureus ATCC 25923 produced the largest inhibition zone. Staphylococcus spp. tested produced significantly larger inhibition zones than Bacillus spp.

King cobra venom was also tested against six gram-negative bacteria using three different concentrations of the venom (Table 2). The inhibition zones also increased with increasing venom concentration. King cobra venom was most efficient against Escherichia coli and was least effective against Pseudomonas aeruginosa.

\section{Purification of the Antibacterial Protein}

Following Sephadex G-75 gel filtration (Figure 1) and the antibacterial screening of gel filtration fractions (Table 3); Q Sepharose ${ }^{\text {Tm }}$ HP (Figure 2) and the antibacterial screening of anion exchange fractions (Table 4); as well as heparin affinity chromatography (Figure 3 ) and the antibacterial screening of affinity chromatography fractions (Table 5) a homogenous protein was obtained. SDS-PAGE was used to analyze the degree of isolation of the LAAO protein with each chromatography step (Figure 4 - A). Under silver staining, LAAO protein showed a high level of purity with an estimated molecular weight of $68 \mathrm{kDa}$ and $70 \mathrm{kDa}$ under reducing and nonreducing conditions respectively (Figure $4-\mathrm{B}$ ).

\section{Identification of Antibacterial Protein Using Mass Spectrometry}

MALDI-TOF was performed on the reduced gel band. Using Mascot database search, peptide mass fingerprinting confirmed the identity of the antibacterial protein as L-amino acid oxidase (LAAO) from the King cobra venom.

\section{Antibacterial Action of the LAAO Enzyme from King Cobra Venom}

Table 6 shows the MICs of LAAO enzyme from king cobra venom against several gram-positive and gram-negative bacteria. LAAO enzyme of king cobra venom has a MIC value of $7.5 \mu \mathrm{g} /$ $\mathrm{mL}$ against all three subtypes of Staphylococcus aureus, and $55.0 \mu \mathrm{g} / \mathrm{mL}$ against Pseudomonas aeruginosa ATCC 27853.

Table 1. Diameter of antibacterial inhibition zones for gram-positive bacteria

\begin{tabular}{|c|c|c|c|c|}
\hline \multirow[b]{2}{*}{ Bacteria } & \multicolumn{3}{|c|}{ Crude venom (mg/mL) } & \multirow{2}{*}{$\begin{array}{l}\text { Vancomycin } 30 \mu \mathrm{g} / \\
\mathrm{mL}(\mathrm{mm})\end{array}$} \\
\hline & $1.0(\mathrm{~mm})$ & $1.5(\mathrm{~mm})$ & $2.0(\mathrm{~mm})$ & \\
\hline $\begin{array}{l}\text { Staphylococcus aureus ATCC } \\
25923\end{array}$ & $8.0 \pm 0.0$ & $9.0 \pm 0.0$ & $9.0 \pm 0.0$ & $8.0 \pm 0.0$ \\
\hline $\begin{array}{c}\text { MRSA } \\
\text { ATCC 43300 }\end{array}$ & $7.3 \pm 0.6$ & $7.3 \pm 0.6$ & $7.7 \pm 0.6$ & $8.3 \pm 0.6$ \\
\hline $\begin{array}{c}\text { Staphylococcus aureus ATCC } \\
29213\end{array}$ & $7.0 \pm 0.0$ & $8.0 \pm 0.0$ & $8.3 \pm 0.6$ & $8.0 \pm 0.6$ \\
\hline $\begin{array}{c}\text { Staphylococcus epidermidis } \\
\text { ATCC } 12228\end{array}$ & $6.7 \pm 0.6$ & $7.0 \pm 0.0$ & $7.7 \pm 0.6$ & $8.3 \pm 0.0$ \\
\hline $\begin{array}{l}\text { Bacillus subtilis } \\
\text { ATCC } 6633\end{array}$ & $2.0 \pm 0.0$ & $2.0 \pm 0.0$ & $3.3 \pm 0.6$ & $7.7 \pm 0.6$ \\
\hline $\begin{array}{l}\text { Bacillus cereus } \\
\text { ATCC } 10987\end{array}$ & - & - & $1.7 \pm 0.6$ & $6.7 \pm 0.6$ \\
\hline
\end{tabular}

Values shown are mean $\pm S D(n=3)$ and represent a venom inhibition zone in millimeters $(\mathrm{mm})$, excluding 4 mm diameter of the well, after 24 hours of incubation at $37^{\circ} \mathrm{C}$. - : no activity. The bacterial inocula per plate contained $1 \times 10^{8}$ colony forming units, which were introduced onto Mueller-Hinton agar surfaces. Holes of $4 \mathrm{~mm}$ were made onto the agar surface and venom was added. 
Table 2. Diameter of antibacterial inhibition zones for gram-negative bacteria

\begin{tabular}{c|c|c|c|c}
\hline \multirow{2}{*}{ Bacteria } & \multicolumn{3}{|c|}{ Crude venom $(\mathrm{mg} / \mathrm{mL})$} & \multirow{2}{*}{$\begin{array}{c}\text { Doxycycline } 30 \mathrm{\mu g} / \\
\mathrm{mL}(\mathrm{mm})\end{array}$} \\
\cline { 2 - 4 } & $1.0(\mathrm{~mm})$ & $1.5(\mathrm{~mm})$ & $\mathbf{2 . 0}(\mathrm{mm})$ & $10.7 \pm 0.6$ \\
\hline $\begin{array}{c}\text { Salmonella enteritidis } \\
\text { ATCC 13076 }\end{array}$ & - & $2.7 \pm 0.6$ & $3.3 \pm 0.6$ & $6.3 \pm 0.6$ \\
\hline $\begin{array}{c}\text { Pseudomonas aeruginosa } \\
\text { ATCC 27853 }\end{array}$ & - & - & $1.0 \pm 0.0$ & $8.7 \pm 0.6$ \\
\hline $\begin{array}{c}\text { Serratia marcescens } \\
\text { ATCC 21074 }\end{array}$ & $1.0 \pm 0.0$ & $1.7 \pm 0.6$ & $2.7 \pm 0.6$ & $11.0 \pm 0.0$ \\
\hline $\begin{array}{c}\text { Klebsiella pneumoniae } \\
\text { ATCC 13883 }\end{array}$ & - & $2.0 \pm 0.0$ & $2.3 \pm 0.6$ & $13.0 \pm 0.0$ \\
\hline $\begin{array}{c}\text { Escherichia coli } \\
\text { ATCC 25922 }\end{array}$ & $1.7 \pm 0.6$ & $3.3 \pm 0.6$ & $3.7 \pm 0.6$ & $10.7 \pm 0.6$ \\
\hline $\begin{array}{c}\text { Enterobacter cloacae } \\
\text { ATCC 13047 }\end{array}$ & - & $1.0 \pm 0.0$ & $1.3 \pm 0.6$ & \\
\hline
\end{tabular}

Values shown are mean $\pm S D(n=3)$ and represent a venom inhibition zone in millimeters $(\mathrm{mm})$, excluding 4 mm diameter of the well, after 24 hours incubation at $37^{\circ} \mathrm{C}$. -: no activity. The bacterial inocula per plate contained $1 \times 10^{8}$ colony forming units, which were introduced onto Mueller-Hinton agar surfaces. Holes of $4 \mathrm{~mm}$ were made onto the agar surface and venom was added.

Table 3. Diameter of antibacterial inhibition zones for gel filtration fractions

\begin{tabular}{|c|c|c|c|c|c|c|}
\hline Bacteria & $\begin{array}{c}\mathrm{P} 1 \\
1.0 \mathrm{mg} / \\
\mathrm{mL}(\mathrm{mm})\end{array}$ & $\begin{array}{c}\mathrm{P} 2 \\
1.0 \mathrm{mg} / \\
\mathrm{mL}(\mathrm{mm})\end{array}$ & $\begin{array}{c}\mathrm{P3} \\
1.0 \mathrm{mg} / \\
\mathrm{mL}(\mathrm{mm})\end{array}$ & $\begin{array}{c}\mathrm{P} 4 \\
1.0 \mathrm{mg} / \\
\mathrm{mL}(\mathrm{mm})\end{array}$ & $\begin{array}{c}\text { Vancomycin } 30 \\
\mu \mathrm{g} / \mathrm{mL} \\
(\mathrm{mm})\end{array}$ & PBS \\
\hline $\begin{array}{c}\text { MRSA } \\
\text { ATCC } 43300\end{array}$ & $7.3 \pm 0.6$ & - & - & - & $9.3 \pm 0.6$ & - \\
\hline $\begin{array}{c}\text { Staphylococcus aureus } \\
\text { ATCC } 25923\end{array}$ & $8.0 \pm 0.0$ & - & - & - & $10.0 \pm 1.2$ & -- \\
\hline $\begin{array}{c}\text { Staphylococcus aureus } \\
\text { ATCC } 29213\end{array}$ & $8.3 \pm 1.2$ & - & - & - & $9.0 \pm 0.0$ & - \\
\hline
\end{tabular}

Values shown are mean $\pm S D(n=3)$ and represent a venom inhibition zone in millimeters $(\mathrm{mm})$, excluding 4 mm diameter of the well, after 24 hours incubation at $37^{\circ} \mathrm{C}$. -: no activity. Holes of $4 \mathrm{~mm}$ were made onto the Mueller-Hinton agar surface and $30 \mu \mathrm{L}$ of gel filtration fraction was added.

Table 4. Diameter of antibacterial inhibition zones for anion exchange fractions

\begin{tabular}{c|c|c|c|c|c|c|c|c}
\hline Bacteria & $\begin{array}{c}P^{\prime} 0 \\
(\mathrm{~mm})\end{array}$ & $\mathrm{P}^{\prime} 1(\mathrm{~mm})$ & $\mathrm{P}^{\prime} 2(\mathrm{~mm})$ & $\begin{array}{c}\mathrm{P}^{\prime} 3 \\
(\mathrm{~mm})\end{array}$ & $\begin{array}{c}\mathrm{P}^{\prime} 4 \\
(\mathrm{~mm})\end{array}$ & $\begin{array}{c}\mathrm{P}^{\prime} 5 \\
(\mathrm{~mm})\end{array}$ & $\begin{array}{c}\text { Vancomycin } \\
\mathbf{3 0 \mathrm { mg } / \mathrm { mL }} \\
(\mathrm{mm})\end{array}$ & PBS \\
\hline $\begin{array}{c}\text { MRSA } \\
\text { ATCC 43300 }\end{array}$ & - & $2.0 \pm 0.0$ & $8.7 \pm 0.0$ & $6.3 \pm 0.6$ & - & - & $10.3 \pm 0.6$ & - \\
\hline $\begin{array}{c}\text { Staphylococcus } \\
\text { aureus } \\
\text { ATCC 25923 }\end{array}$ & - & $3.3 \pm 0.6$ & $10.0 \pm 0.6$ & $7.3 \pm 0.6$ & - & - & $10.0 \pm 0.0$ & - \\
\hline $\begin{array}{c}\text { Staphylococcus } \\
\text { aureus } \\
\text { ATCC 29213 }\end{array}$ & - & $2.7 \pm 0.0$ & $9.0 \pm 0.6$ & $6.3 \pm 0.6$ & - & - & $10.0 \pm 0.0$ & - \\
\hline
\end{tabular}

Values shown are mean $\pm S D(n=3)$ and represent a venom inhibition zone in millimeters $(\mathrm{mm})$, excluding diameter of the well, after 24 hours incubation at $37^{\circ} \mathrm{C}$. --: no activity. Holes of $4 \mathrm{~mm}$ were made onto the Mueller-Hinton agar surface and $30 \mu \mathrm{L}$ of anion exchange fraction was added. 
Table 5. Diameter of antibacterial inhibition zones for affinity chromatography fractions

\begin{tabular}{c|c|c|c|c|c|c|c}
\hline Bacteria & $\mathbf{P}^{\circ} \mathbf{0}(\mathrm{mm})$ & $\begin{array}{c}\mathbf{P}^{\circ} 1 \\
(\mathbf{m m})\end{array}$ & $\begin{array}{c}\mathbf{P}^{\circ} 2 \\
(\mathbf{m m})\end{array}$ & $\begin{array}{c}\mathbf{P}^{\circ} 3 \\
(\mathbf{m m})\end{array}$ & $\begin{array}{c}\mathbf{P}^{\circ} 4 \\
(\mathbf{m m})\end{array}$ & $\begin{array}{c}\text { Vancomycin 30 } \\
\mu \mathrm{g} / \mathrm{mL}(\mathbf{m m})\end{array}$ & $\mathrm{PBS}$ \\
\hline $\begin{array}{c}\text { MRSA } \\
\text { ATCC 43300 }\end{array}$ & $8.0 \pm 0.6$ & - & - & - & - & $9.7 \pm 0.0$ & - \\
\hline $\begin{array}{c}\text { Staphylococcus aureus } \\
\text { ATCC 25923 }\end{array}$ & $9.0 \pm 0.0$ & - & - & - & - & $10.0 \pm 0.6$ & - \\
\hline $\begin{array}{c}\text { Staphylococcus aureus } \\
\text { ATCC 29213 }\end{array}$ & $8.7 \pm 0.6$ & - & - & - & - & $9.3 \pm 0.6$ & - \\
\hline
\end{tabular}

Values shown are mean $\pm S . D(n=3)$ and represent a venom inhibition zone in millimeters $(\mathrm{mm})$, excluding 4 mm diameter of the well, after 24 hours of incubation at $37^{\circ} \mathrm{C}$. -: no activity. Holes of $4 \mathrm{~mm}$ were made onto the Mueller-Hinton agar surface and $30 \mu \mathrm{L}$ of affinity chromatography fraction was added.

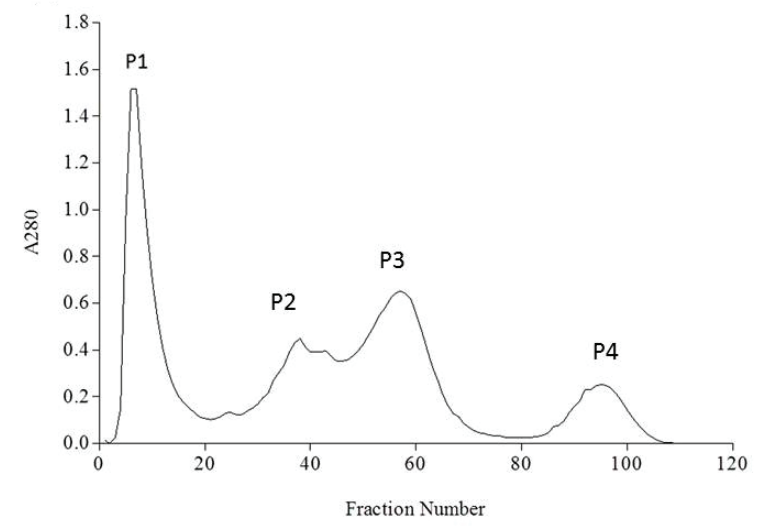

Figure 1. Sephadex ${ }^{\top M}$ G-75 gel filtration chromatography of $100 \mathrm{mg}$ of king cobra venom. Column was previously equilibrated with ammonium acetate (50 mM, pH 7.0). P1: peak 1, P2: peak 2, P3: peak 3, P4: peak 4.

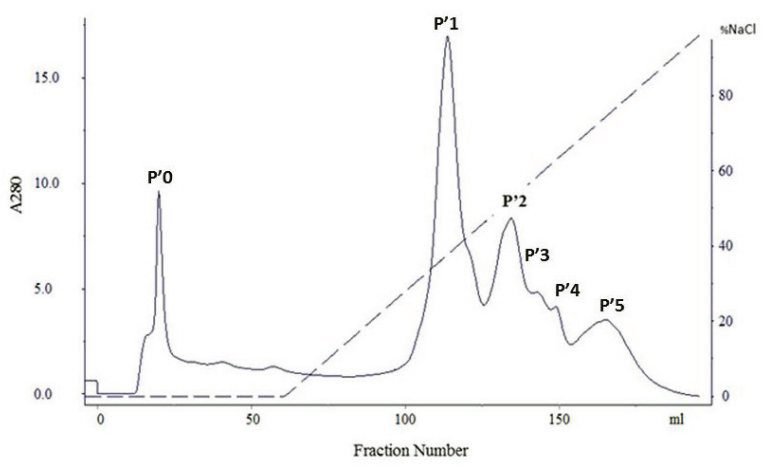

Figure 2. QSepharose ${ }^{\mathrm{TM}}$ High Performance anion exchange chromatography of $7 \mathrm{mg}$ of gel filtration fraction one (P1). Column was previously equilibrated with tris- $\mathrm{HCl}(20 \mathrm{mM}, \mathrm{pH}$ 7.6). A linear $\mathrm{NaCl}$ gradient of $0-0.5 \mathrm{M} \mathrm{NaCl}$ was employed for elution. $P^{\prime} 0$ : unbound peak, $\mathrm{P}^{\prime} 1$ : peak 1, $\mathrm{P}^{\prime} 2$ : peak 2 , $\mathrm{P}^{\prime}$ 3: peak 3, $\mathrm{P}^{\prime} 4$ : peak 4; $\mathrm{P}^{\prime} 5$ : peak 5.

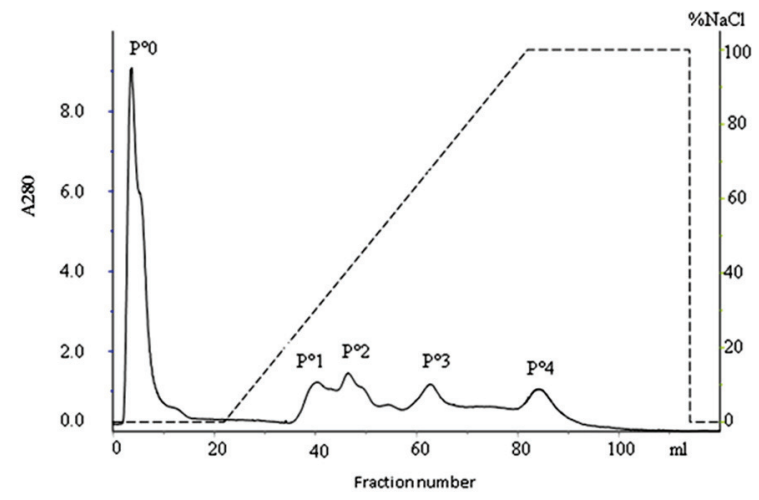

Figure 3. HiTrap ${ }^{\mathrm{TM}}$ Heparin HP affinity chromatography of anion exchange fraction $\mathrm{P}^{\prime} 2$. Column was previously equilibrated with tris- $\mathrm{HCl}$ (20 mM, pH 7.6). A linear $\mathrm{NaCl}$ gradient of $0-0.5 \mathrm{M}$ $\mathrm{NaCl}$ was employed for elution. $\mathrm{P}^{\circ} 0$ : unbound peak, $\mathrm{P}^{\circ} 1$ : peak 1, $\mathrm{P}^{\circ} 2$ : peak 2, $\mathrm{P}^{\circ} 3$ : peak 3, $\mathrm{P}^{\circ} 4$ : peak 4. 


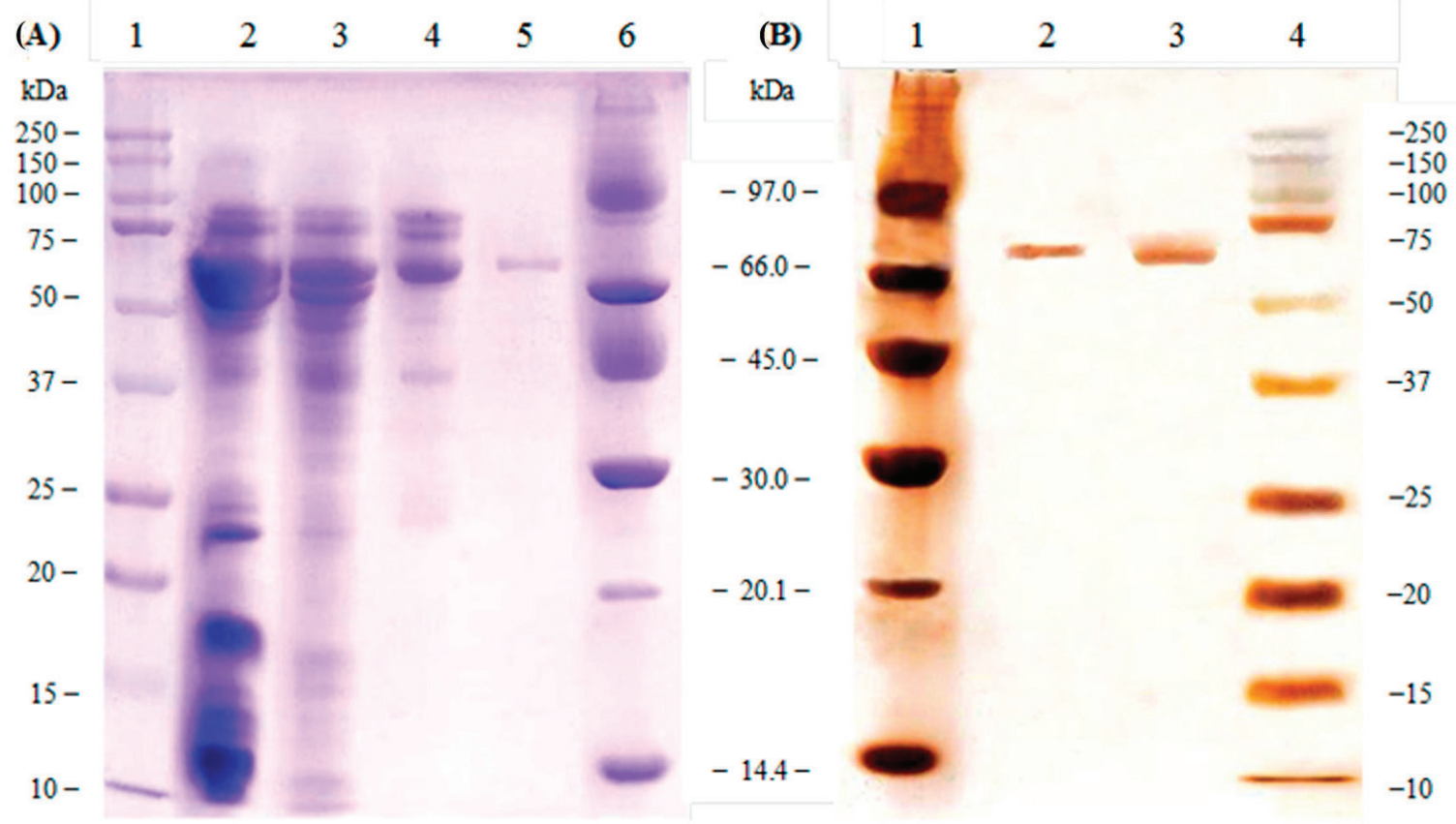

Figure 4. (A) SDS-PAGE of the LAAO fractions from the three purification steps in 12.5\% gel. Lane 1: Precision Plus Protein ${ }^{\mathrm{TM}}$ Kaleidoscope ${ }^{\mathrm{TM}}$ standards molecular weight marker; lane 2: crude king cobra venom; lane 3: gel filtration chromatography fraction P1; lane 4: anion exchange chromatography fraction P'2; lane 5: affinity chromatography fraction $\mathrm{P}^{\circ} 0$; lane 6: Amersham ${ }^{\mathrm{TM}}$ Low Molecular Weight SDS electrophoresis marker. (B) SDS-PAGE with silver staining of LAAO. Lane 1: Amersham $^{\text {TM }}$ Low Molecular Weight SDS electrophoresis marker; lane 2: isolated antibacterial constituent under reducing conditions; lane 3: isolated antibacterial constituent under non-reducing conditions; lane 4: Precision Plus Protein ${ }^{\mathrm{TM}}$ Kaleidoscope $^{\mathrm{TM}}$ Standards molecular weight marker.

Table 6. MIC values of LAAO enzyme from king cobra venom against six gram-positive and six gramnegative bacteria

\begin{tabular}{c|c}
\hline Bacteria & MIC of LAAO $(\mu \mathrm{g} / \mathrm{mL})$ \\
\hline Staphylococcus aureus ATCC 25923 & 7.5 \\
\hline Staphylococcus aureus ATCC 29213 & 7.5 \\
\hline Methicillin resistant Staphylococcus aureus ATCC 43300 & 7.5 \\
\hline Staphylococcus epidermidis ATCC 12228 & 7.5 \\
\hline Bacillus subtilis ATCC 6633 & 55.0 \\
\hline Bacillus cereus ATCC 10987 & 55.0 \\
\hline Salmonella enteritidis ATCC 13076 & 55.0 \\
\hline Pseudomonas aeruginosa ATCC 27853 & 55.0 \\
\hline Serratia marcescens ATCC 21074 & 55.0 \\
\hline Klebsiella pneumoniae ATCC 13883 & 55.0 \\
\hline Escherichia coli ATCC 25922 & 27.5 \\
\hline Enterobacter cloacae ATCC 13047 & 110.0 \\
\hline
\end{tabular}

MICs of LAAO enzyme from king cobra venom. MIC was determined using radial diffusion assay method. Serial twofold dilutions of the purified antibacterial constituent from king cobra venom were done. The MIC was determined as the minimum concentration of LAAO enzyme forming a visually detectable clear zone larger than the size of the well $(4 \mathrm{~mm})$ under the current experimental conditions. 


\section{Antifungal Screening of King Cobra Venom}

In our antifungal test using $1.0 \mathrm{mg} / \mathrm{mL}, 1.5 \mathrm{mg} /$ $\mathrm{mL}$ and $2.0 \mathrm{mg} / \mathrm{mL}$ of crude king cobra venom no visible inhibition zones were seen.

\section{DISCUSSION}

\section{The Antibacterial Activity of Crude King Cobra Venom}

Although both species of bacteria are grampositive, king cobra venom is more efficacious against Staphylococcus spp. than against Bacillus spp. This is possibly due to the LAAO enzyme substrate specificity (23). Furthermore, this seems to be the case for not just king cobra venom, but also other types of snake venom $(3,10)$. Although Stiles et al. (10) screened a total of 21 species of Elapidae snakes (king cobra was not included), and none showed any significant effects against Pseudomonas aeruginosa or even Escherichia coli, it was surprising to discover that king cobra venom showed antibacterial activity against both Escherichia coli and Pseudomonas aeruginosa.

This finding suggests that the LAAO enzyme of king cobra is a distinctive variant of snake LAAOs. Inhibition zones for Staphylococcus spp. were at least double the size of the other bacteria. Therefore, king cobra venom could have a narrow spectrum of antibacterial activity. In comparison to the study carried out on crossed pit viper (Bothrops alternatus), which also used the similar hole-plate method for screening, the order of susceptibility of bacteria to the venom was as follows: Escherichia coli > Staphylococcus aureus $>$ Pseudomonas aeruginosa (24). In our study, however, Staphylococcus aureus was more susceptible to king cobra venom than Escherichia coli.

\section{The King Cobra Venom LAAO Enzyme}

Of the many different LAAO enzymes of various snake species, the king cobra venom LAAO enzyme is unique in its own way. The enzyme constitutes approximately $25.5 \%$ of the venom (25). In our study, despite repeated freezing of chromatographic fractions, the antibacterial activity of LAAO enzyme was retained. It has been reported that the LAAO enzyme of king cobra venom has unusual high thermal stability as it is not inactivated by freezing, and retains complete enzymatic activity even after heating at $55^{\circ} \mathrm{C}$ for 40 minutes (26).
The LAAO enzyme of king cobra venom shares a sequence identity of only around $50 \%$ with other snake venom LAAOs. It is noteworthy that except for LAAO enzyme of king cobra venom, the sequence identities among snake venom LAAOs are extremely high. Amongst elapid snake venom LAAOs, the sequence identities are all more than $85 \%$ except for King cobra (27). It is believed that the antibacterial effect of LAAO enzyme is due to the hydrogen peroxide liberated, since the addition of catalase completely suppresses the antibacterial activity (28). Electron microscopic studies suggested that the hydrogen peroxide generated in the oxidation process induces bacterial membrane rupture and then cell death (29). The LAAO enzyme of Siberian pit viper venom (Agkistrodon halys) was reported to be able to bind to surfaces of bacteria and generate high concentrations of hydrogen peroxide locally, which enabled the enzyme to inhibit bacterial growth (30). It is not clear whether this happens to other snake venom LAAOs as well.

\section{Sodium Dodecyl Sulfate Polyacrylamide Gel Electrophoresis (SDS-PAGE)}

From our SDS-PAGE, we found that the LAAO enzyme has an estimated molecular weight of 68 $\mathrm{kDa}$ and $70 \mathrm{kDa}$ under reducing and non-reducing conditions, respectively. Another study estimated king cobra LAAO enzyme's molecular weight to be $150 \mathrm{kDa}$ by gel filtration chromatography and $70 \mathrm{kDa}$ under SDS-PAGE (31). Another report showed that king cobra LAAO enzyme has an estimated molecular weight of $64 \mathrm{kDa}$ by SDSPAGE (27).

Since the molecular weight of king cobra LAAO enzyme was reduced by about half under denaturing conditions of SDS-PAGE, the LAAO enzyme could be homodimeric. This was also reported by Ahn et al. (31). The LAAO enzyme gel band was compared under reducing and nonreducing conditions. The reduced protein gel band was slightly higher, and this was consistent with a report by Jin et al. (27), in which the reduced LAAO enzyme gel band was $3 \mathrm{kDa}$ higher that the non-reduced gel band.

\section{MIC of King Cobra Venom LAAO Enzyme}

Comparing the antibacterial inhibition zones when using crude venom and when using the isolated LAAO enzyme, the LAAO enzyme was found to give an inhibition zone of similar size 
but at a much lower concentration than that of crude venom. This is probably due to the high purity of the isolated LAAO enzyme. A recent study on Siamese Russell's viper (Daboia russellii siamensis) compared the MIC of king cobra LAAO enzyme with other LAAOs, the MIC of the Siamese Russell's viper LAAO enzyme against Staphylococcus aureus ATCC 25923, Pseudomonas aeruginosa ATCC 27853 and Escherichia coli ATCC 25922 was $9.0 \mu \mathrm{g} / \mathrm{mL}, 144.0 \mu \mathrm{g} / \mathrm{mL}$ and $288.0 \mu \mathrm{g} / \mathrm{mL}$, all of which were higher than the MIC of king cobra LAAO (32).

Apart from LAAO enzyme, other snake venom proteins also possess antibacterial activity. Of particular relevance is the snake venom peptide, cathelicidin, which was recently cloned from the venom gland cDNA library of king cobra (15). The recombinant cathelicidin from king cobra venom reportedly showed remarkable antibacterial activity, particularly against gram-negative bacteria. In our study, although a screening of the fractions of king cobra venom was done, we could not detect cathelicidin. This could be because unlike the LAAO enzyme which is found in much larger quantities in snake venom, the cathelicidin peptide is present at much lower levels and is thus difficult to detect.

\section{ACKNOWLEDGEMENTS}

The authors would like to thank the International Medical University of Malaysia for the support.

\section{COPYRIGHT}

(C) CEVAP 2012

\section{SUBMISSION STATUS}

Received: November 17, 2011.

Accepted: February 17, 2012.

Abstract published online: March 6, 2012.

Full paper published online: May 31, 2012.

\section{CONFLICTS OF INTEREST}

The authors declare no conflicts of interest.

\section{FINANCIAL SOURCE}

The International Medical University, Malaysia, provided the financial grants.

\section{ETHICS COMMITTEE APPROVAL}

The present study was approved by the $30^{\text {th }}$ IMU Joint-Committee of the Research and Ethics Committee under the identification number BMSc I-01/2010, International Medical University of Malaysia.

\section{CORRESPONDENCE TO}

Chun Seng Phua, Faculty of Medicine and Health, International Medical University, Kuala Lumpur, Malaysia. Phone: +603 22742136. Email: chunsengphua@yahoo.com.

\section{REFERENCES}

1. Ang JY, Ezike E, Asmar BI. Antibacterial resistance. Indian J Pediatr. 2004;71(3):229-39.

2. Barbosa TM, Levy SB. The impact of antibiotic use on resistance development and persistence. Drug Resist Updat. 2000;3(5):303-11.

3. Talan DA, Citron DM, Overturf GD, Singer B, Froman P, Goldstein EJ. Antibacterial activity of crotalid venoms against oral snake flora and other clinical bacteria. J Infect Dis. 1991;164(1):195-8.

4. Thomas RG, Pough FH. The effect of rattlesnake venom on digestion of prey. Toxicon. 1979;17(3):2218.

5. Glaser HSR. Bactericidal activity of Crotalus venom in vitro. Copeia. 1948;4:245-7.

6. Ciscotto P, Machado de Avila RA, Coelho EA, Oliveira J, Diniz CG, Farías LM, et al. Antigenic, microbicidal and antiparasitic properties of an l-amino acid oxidase isolated from Bothrops jararaca snake venom. Toxicon. 2009;53(3):330-41.

7. Stábeli RG, Marcussi S, Carlos GB, Pietro RC, Selistrede-Araújo HS, Giglio JR, et al. Platelet aggregation and antibacterial effects of an l-amino acid oxidase purified from Bothrops alternatus snake venom. Bioorg Med Chem. 2004;12(11):2881-6.

8. Stocker JF, Traynor JR. The action of various venoms on Escherichia coli. J Appl Bacteriol. 1986;61(5):383-8.

9. Izidoro LF, Ribeiro MC, Souza GR, Sant'Ana CD, Hamaguchi A, Homsi-Brandeburgo MI, et al. Biochemical and functional characterization of an L-amino acid oxidase isolated from Bothrops pirajai snake venom. Bioorg Med Chem. 2006;14(20):703443.

10. Stiles BG, Sexton FW, Weinstein SA. Antibacterial effects of different snake venoms: purification and characterization of antibacterial proteins from Pseudechis australis (Australian king brown or mulga snake) venom. Toxicon. 1991;29(9):1129-41.

11. Perumal Samy R, Pachiappan A, Gopalakrishnakone $\mathrm{P}$, Thwin MM, Hian YE, Chow VT, et al. In vitro antimicrobial activity of natural toxins and animal venoms tested against Burkholderia pseudomallei. BMC Infect Dis. 2006;6(1):100.

12. Rodrigues RS, da Silva JF, Boldrini França J, Fonseca FP, Otaviano AR, Henrique Silva F, et al. Structural and functional properties of Bp-LAAO, a new L-amino acid oxidase isolated from Bothrops pauloensis snake venom. Biochimie. 2009;91(4):490-501.

13. Perumal Samy R, Gopalakrishnakone P, Ho B, Chow VT. Purification, characterization and bactericidal 
activities of basic phospholipase A2 from the venom of Agkistrodon halys (Chinese pallas). Biochimie. 2008;90(9):1372-88.

14. Gold BS, Pyle P. Successful treatment of neurotoxic king cobra envenomation in Myrtle Beach, South Carolina. Ann Emerg Med. 1998;32(6):736-8.

15. Zhao H, Gan TX, Liu XD, Jin Y, Lee WH, Shen JH, et al. Identification and characterization of novel reptile cathelicidins from elapid snakes. Peptides. 2008;29(10):1685-91.

16. Lee ML, Tan NH, Fung SY, Sekaran SD. Antibacterial action of a heat-stable form of L-amino acid oxidase isolated from king cobra (Ophiophagus hannah) venom. Comp Biochem Physiol C Toxicol Pharmacol. 2011;153(2):237-42.

17. San TM, Vejayan J, Shanmugan K, Ibrahim $\mathrm{H}$. Screening antimicrobial activity of venoms from snakes commonly found in Malaysia. J Appl Sci. 2010;10(19):2328-32.

18. Nair DG, Fry BG, Alewood P, Kumar PP, Kini RM. Antimicrobial activity of omwaprin, a new member of the waprin family of snake venom proteins. Biochem J. 2007;402(1):93-104.

19. Laemmli UK. Cleavage of structural Proteins during the assembly of the head of bacteriophage T4. Nature. 1970;227(5259):680-5.

20. Bradford MM. A rapid and sensitive method for the quantitation of microgram quantities of protein utilizing the principle of protein-dye binding. Anal Biochem. 1976;72(1):248-54.

21. CLSI - Clinical and Laboratory Standards Institute. Methods for dilution antimicrobial susceptibility tests for bacteria that grow aerobically; approved standards. 7th ed. Wayne, PA: Clinical and Laboratory Standards Institute; 2006.

22. Takemura H, Kaku M, Kohno S, Hirakata Y, Tanaka H, Yoshida R, et al. Evaluation of susceptibility of grampositive and -negative bacteria to human defensins by using radial diffusion assay. Antimicrob Agents Chemother. 1996;40(10):2280-4.
23. Tan NH, Saifuddin MN. Substrate specificity of king cobra (Ophiophagus hannah) venom L-amino acid oxidase. Int J Biochem. 1991;23(3):323-7.

24. Bustillo S, Leiva LC, Merino L, Acosta O, Kier Joffé EB, Gorodner JO. Antimicrobial activity of Bothrops alternatus venom from the Northeast of Argentine. Rev Latinoam Microbiol. 2008;50(3-4):79-82.

25. LiZY, Yu TF, Lian EC. Purification and characterization of L-amino acid oxidase from king cobra (Ophiophagus hannah) venom and its effects on human platelet aggregation. Toxicon. 1994;32(11):1349-58.

26. Tan NH, Saifuddin MN. Isolation and characterization of an unusual form of L-amino acid oxidase from King cobra (Ophiophagus hannah) venom. Biochem Int. 1989;19(4):937-44.

27. Jin Y, Lee WH, Zeng L, Zhang Y. Molecular characterization of L-amino acid oxidase from king cobra venom. Toxicon. 2007;50(4):479-89.

28. Tan NH, Fung SY. Snake venom L-amino acid oxidases and their potential biomedical applications. Mal J Biochem Mol Biol. 2008;16(1):1-10.

29. Toyama MH, Toyama D de O, Passero LF, Laurenti MD, Corbett CE, Tomokane TY, et al. Isolation of a new L-amino acid oxidase from Crotalus durissus cascavella venom. Toxicon. 2006;47(1):47-57.

30. Zhang H, Yang Q, Sun M, Teng M, Niu L. Hydrogen peroxide produced by two amino acid oxidases mediates antibacterial actions. J Microbiol. 2004;42(4):336-9.

31. Ahn MY, Lee BM, Kim YS. Characterization and cytotoxicity of L-amino acid oxidase from the venom of king cobra (Ophiophagus hannah). Int J Biochem Cell Biol. 1997;29(6):911-9.

32. Zhong SR, Jin Y, Wu JB, Jia YH, Xu GL, Wang GC, et al. Purification and characterization of a new L-amino acid oxidase from Daboia russellii siamensis venom. Toxicon. 2009;54(6):763-71. 